Pakistan Journal of Humanities and Social Sciences

October - December 2018, Volume 6, No. 4, Pages 477 - 491

\title{
Effects of Corporate Social Responsibility on Consumer Purchase Intention
}

Fawad Ali $^{1}$, Maarif Sohail ${ }^{2}$

${ }^{1}$ M.B.A, University of the Punjab, Lahore, Pakistan

${ }^{2}$ M.B.A(Finance), University of Texas Arlington, USA

Email: maarifsohail@yahoo.com

\begin{abstract}
The aim of this study was to identify the impact of corporate social responsibility on the purchase intention of customers. Corporate Social Responsibility was measured on the basis of five factors, namely Customer Centric, Green Environment, Philanthropy, Public Awareness and Creating Shared Values. This was a quantitative, deductive and cross-sectional study. Convenience sampling technique was used to collect the data from 300 respondents from the University of the Punjab, Lahore. IBM-SPSS was used to analyses the data and regression was run to test hypotheses. Findings of the research suggested that Customer Centric, Green Environment Philanthropy, Public Awareness and Creating Shared Value do have a significant impact on the purchase intention of the consumers. Theoretical and practical contributions along with limitations and future direction are also discussed of the study.
\end{abstract}

Keywords: Customer Centric, Green Environment, Philanthropy, Public Awareness, Creating Shared Values, Purchase Intention

\section{Introduction}

With the increasing competition companies are on their toes to do things that can give them that very competitive edge. Analysts have found out that, in order to be in the good books of the public, it has to do something that is beneficial to public, especially to the target audience. Every modern corporation is expected to have some social responsibilities to fulfill. This is termed as Corporate Social Responsibility (CSR). Companies follow CSR in order to improve their brand reputation in the market. Improvement of brand image in the minds of customer can affect the overall perception of a customer towards a brand. This might bring about changes in the purchase intention and preference. Research has uncovered that a developing number of purchasers empower and value company's intentional exercises that emphatically add to society (Lee \& Lee, 2015). In an overview by McKinsey, $89 \%$ of customers underwrite and bolster 
organizations that adjust their commitments to their stakeholders and make commitments to the more extensive basic good (Ramasamy, \& Yeung, 2009). Consequently, organization's willful duties, for example, monetary, legitimate, moral, and philanthropic towards a general public in which it works have been considered as CSR exercises (Carroll, 1979). As it were business organizations are to make benefit as well as are dependable to a general public inside which they work (Fatma, \& Rahman, 2016). Research has uncovered that buyer demonstrates positive reaction towards organizations occupied with CSR exercises (Parsa, Lord, Putrevu, \& Kreeger, 2015). In this manner, the CSR exercises essentially add to business organizations' image, buyers' buy goal, and company's long haul execution (Lee \& Lee, 2015). Despite the fact that examination ponders report a positive impact of company's CSR exercises on purchaser's buy expectation and purchasing choices (Parsa et al., 2015; Lee \& Lee, 2015), (Fatma, \& Rahman, 2016) think about the discoveries, generally, uncertain. A few examinations have opined that customers are not especially intrigued by firm's CSR exercises since they more often than not concentrate more on their self-advantage. Consequently, the CSR exercises, generally, don't identify with organization results (Vaaland, Heide, \& Grønhaug, 2008). Besides, the majority of the experimental work on CSR theme has been done in Anglo-Saxon nations, e.g., U.S. what's more, U.K. Research uncovered that there have been a couple of investigations of buyer reactions to CSR in Pakistan. In this way, it is critical to see how CSR activities were taken in different nations and social settings, particularly in Pakistan, impact shopper reaction (Lee, \& Shin, 2010). The vital inquiries that have not been replied in writing expressly are: What are the impacts of distinctive kinds of CSR on buyers buying decision? This study examines the relationship between different types of CSR activities and consumer purchase intention. It investigates the hidden system between firm's CSR and buyer buy expectation. The reason why researcher chooses the sample from Punjab University is that it's one of the biggest public sector University of Pakistan. It's Asia's largest University. There are more than thirty thousand students studying who belong to different provinces and various backgrounds. Pakistan currently has the largest population of young people, according to the National Human Development Report released by the UNDP in 2018. Buyer choice or Purchaser decision making has for some been significant to analysts. Starting around 300 years back early financial investigators, drove by Bernoulli Nicholas, Neumann John von and Oskar Morgenstern, began to take a gander at the possibility of buyer basic decision-making. (Richarme 2007). This early work advanced toward the point from a financial perspective, and focused only on the showing of purchase. (Loudon and Della Bitta 1993). The most widely recognized model starting here 
of view is 'Utility Theory' which proposes that customers settle on choices in perspective of the typical aftereffects of their decisions. Customers are viewed as sound pioneers who are simply stressed over self-interest. (Kanuk and Schiffman 2007, Zinkhan 1992).

\section{Literature Review}

\section{A. Corporate Social Responsibility}

A long history is associated with the impacts of CSR on the organization's behavior. (Moura-Leite, \& Padgett, 2011) have argued over the historical background of CSR. It is necessary to understand and comprehend the development in order to comprehend the impact of CSR on the organization behavior. The main focus in 1950 was the duties of business to society and working for well-being of the society. In the people of the 1960s era, ideas and key events were influential and involved in portraying the social changes occurring during that period (Moura-Leite \& Padgett, 2011). Similarly, Carroll (2008) argued that in the 1970s, traditional management operations were implemented by the business managers in order to deal with the CSR issues, although, in the 1980s, the social and business concerns and interests came closer and companies turned into more receptive and responsive firms to the stakeholders. The idea of CSR was universally accepted in the 1990s, and finally, it turned into a significant strategic matter in the 2000s (Carroll A. B., 2008). So, Crowther (2008) has defined the CSR as the business procedures and practices including the initiatives that are beneficial for society encompassing an extensive range of tactics and strategies like to give charity, to incorporate ethical practices, and to take into account environmental efforts. With the development of CSR, the responsiveness and awareness of stakeholders regarding CSR has boosted with time and they are more concerned about the business practices and procedures than ever before (Beckmann, 2007). Ali (2011) has explained that a wide consideration has been gained by the concept of CSR in business and academic field in the recent years. Organizations are incorporating CSR into their businesses to develop amiable relations with the stakeholders and to gain competitive edge (Ali, 2011). Following (Bigné, Currás, Ruiz, \& Sanz 2012), it can be said that CSR has an extensive range of effects on the consumer behavior and they respond to some initiatives of CSR but not to all of them because of the correspondence fit among the company products and consumer profile, brand characteristics and their knowledge level (Bigné, Currás, Ruiz, \& Sanz, 2012); the professed reliability of the information sources (Robinson, Irmak, \& Jayachandran, 2012); and their response also contrasts relating to the relationships among CSR initiatives and corporate skills (Lichtenstein, Drumwright, \& Braig, 2004).Tian \& Yuan (2013) noted that the companies who incorporate CSR activities in their 
business can gain customers' trust. The results might be customer loyalty (Du, Bhattacharya, \& Sen, 2007), enhanced brand image (Tian \& Yuan, 2013), good response of consumers towards the products and services (Pirsch, Gupta, \& Grau, 2007), improved relationship of customers with the company (Sen, Bhattacharya, \& Korschun, 2006), and decline in the acknowledgement of blame for the unfavorable conditions and event and customer satisfaction (Klein \& Dawar, 2004), and improved consumer purchase intention (Rodrigues \& Borges, 2015). Wong pitch et al. (2016) explained that the attitude of the customers towards the firm is majorly affected by the incorporation of CSR activities and initiatives that in turn positively impacts the consumer buying behavior and purchase intention (Wongpitch, Minakan, Powpaka, \& Laohavichien, 2016).

\section{B. Purchase Intention}

Purchase intention signifies an individual's own willingness to purchase anything. Willingness to buy can be influenced by multiple factors. Brand familiarity and confidence in a brand is one of the major factors that can influence customer purchase intention (Laroche, 1996). A company that indulges in CSR activities helps itself in giving a brand identity and that brand identity acts as a factor that can influence consumer purchase intention (David, Kline, \& Dai, 2005). Therefore, it is understood that a firm is required to behave ethically, not for the customers' sake but for its own sake as well because a firm's approach on being ethical or unethical can greatly influence a customer's purchase intention towards buying from that firm (Creyer, 1997).

\section{Dimensions of CSR}

After doing secondary research and doing some brainstorming, following dimensions of CSR were identified by researcher and each of them is put to operationalization that will eventually help researcher to develop tool for performing research and see whether the proposed relationship does exist or not. The dimensions to measure CSR are; Customer centric; Customer centric is a brand's willingness to be highly customer oriented. It should look to treat each customer with care and respect. A customer who is treated by the company in a manner that the customer himself feels respected, can be affected to such an extent that his purchase intentions might get influenced. Sheth and his colleagues characterized customer centric as 'understanding and fulfilling the requirements, needs and resources of individual buyers or clients instead of those of mass markets or market portions. Green environment; Green environment involves a company doing practices that conserve natural environment. Such practices include having facilities that help to maintain green environment. A company that saves the nature is serving 
its customers by producing minimal health hazard by-products and this act can influence customers to support and hence buy from that particular brand. Brown and Rutledge gave a significant meaning of green business as "a foundation that produces green yield" (Brown, Rutledge, 2011). Green business requires an adjusted commitment to benefit, probability and humankind" (Makower, Pyke, 2009). Philanthropism; Philanthropism is a company's act of giving away charity or to provide the public with any facility at the hour of need (e.g. building a mosque or a park). A company that spends on its public can somehow influence the buying intentions of the customers from that particular brand. Public Awareness; Public awareness is a company's effort to educate people or provoke positive values in them through meaningful advertisements and promotions. A company that appears to be fair to its customers and is happy to guide them, can impact the purchase intention of customers. Public awareness has been defined as "a comprehensive effort that includes multiple components (messaging, grassroots outreach, media relations, government affairs, budget, etc.) to help reach a specific goal" (Bouder, 2013). Creating Social Value; creating social value is the act of a company to train people in order to ensure that they live a better life. By creating a positive social value for people, a brand can impart the purchase intention of its consumers.

\section{Theoretical Framework}

In light of the dimensions identified for CSR, following is the theoretical framework of research. Customer centric, green environment, philanthropism, public awareness and creating social value are all independent factors which will be used to see how they impact the dependent variable, which is the purchase intention.

Figure 1: Theoretical Framework

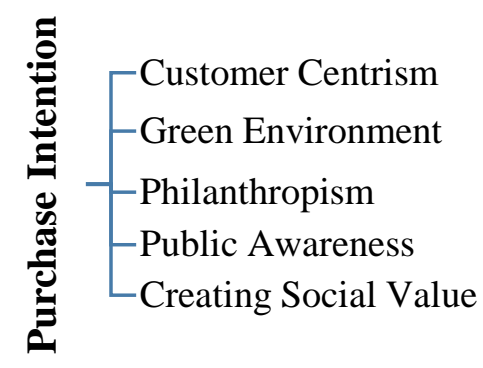




\section{A. Hypothesis Building}

From the above stated dimensions of CSR researcher has introduced, researcher came to the following alternative hypotheses that are being tested.

H1: There is a significant impact of customer centric on purchase intention of customers.

$\mathrm{H} 2$ : There is a significant impact of green environment on purchase intention of customers. H3: There is a significant impact of philanthropism on purchase intention of customers.

H4: There is a significant impact of creating public awareness on purchase intention of customers.

H5: There is a significant impact of creating shared value on purchase intention of customers.

\section{Methodology}

Quantitative form of research is used quantify the effect of CSR on the purchase intention of customers. Structured questionnaire was used to collect the data and then will use the responses to run statistical tests in Statistical Package for the Social Sciences (SPSS) software to quantitatively determine the results of the findings. Since CSR is a well-known term, therefore first of all researcher has to go through multiple journal articles to see what other researchers have to say about CSR. In the light of primary data collection, researcher designs a structured questionnaire, which is the tool for data collection, and then conducted a data collection process of, which will be researcher primary data collection. The responses of each question is measured by means of Likert Scale on a scale of 1 to 5 in the following order: Strongly Agree $(\mathrm{SA})=1$, Agree $(\mathrm{A})=2$, Neutral $(\mathrm{N})=3$, Disagree $(\mathrm{D})=4$ and Strongly Disagree $(\mathrm{SD})=5$. Researcher used convenience sampling to gather the data, in which students of university were preferred (undergraduates and above). This is because, common people are not truly familiar with CSR and therefore the data collected from them will not give us a complete illustration of how CSR is understood in the market. Therefore researcher's preference is students who have a fair idea about CSR and how can it impacts their purchase intention, if it at all does. Researcher used item response theory to select the sample size. Selection of sample size; Due to non-accessibility of the confirmation about correct number of understudies in Punjab University contemplating in different departments. There are diverse researches about who have proposed distinctive example sizes for unknown populace. As indicated by Jackson (2003) N: q manages to evaluate the example estimate in SE. $\mathrm{N}$ is the quantity of parameters and $q$ is statistical estimates. A perfect size proportion is 20:1. Kline (2011) has mentioned a most typical and medium type test estimate in a SEM. As general rule by Hair et al, (2009) least proportion is 5:1 for every factor, except most worthy proportion is 10:1. Most researchers even proposed a minimum of 20:1 ratio for each variable. It also depends 
upon model complexity. Researchers sample size was initially decided to be minimum 300 . The population of researcher is Punjab university students from Lahore, Pakistan studying in different undergraduate and graduate programs. Among the two types of researches i.e. longitudinal and cross sectional, the time horizon for this research is based on cross sectional methodology, a method in which the primary data collection is done only once. This is because researcher was getting questionnaires filled only once and researcher wasn't doing a trend analysis. Since researcher is looking at the impact of independent variable on the dependent variable at the solitary level, therefore the unit of analysis is the individual. Among the three types of studies namely exploratory, descriptive and causal, researcher opted for causal type of study. This is because, the variables in this study are already well recognized which meant that exploratory study is out of question. The motive of research is to find the effect of researcher's independent variable on the dependent variable, therefore causal type of study suits this research. As a trial, researcher has run the questionnaire into pre-testing. 30 respondents were asked to carefully read and fill the questionnaire and the consequent responses from the questionnaire are put to testing on SPSS. After the questionnaire meets the minimum benchmarks on the statistical tool, it is put to practical application. Invalid or incomplete questionnaires were discarded then the data was uploaded in IBM SPSS to run the regression tests. After getting the data from the respondents, researcher converted the data in quantitative terms and then put it through testing using SPSS in order to determine the results of this study. In this questionnaire, starting questions included age, gender, education level and department which are the statistical data of the respondents. There are six constructs in a conceptual Customer centric, green environment, philanthropism, public awareness and creating social value and purchase intention. The definitions and items of these scales were derived from existing scales.

\section{Results}

\section{A. Demographics}

This study received more responses from females. 192 out of the total 300 responses belonged to females, which constitute the $64.0 \%$ of the sample. 108 of the remaining respondents were male and they formed the $36.0 \%$ of the total sample. 
Table 1: Frequency Distribution of Gender

\begin{tabular}{|c|c|c|c|c|}
\hline Gender & Frequency & Percent & Valid percent & Cumulative percent \\
\hline Male & 108 & 36.0 & 36.0 & 36.0 \\
\hline Female & 192 & 64.0 & 64.0 & 100 \\
\hline Total & 300 & 100 & 100 & \\
\hline
\end{tabular}

Table 2: Frequency Distribution of Age

\begin{tabular}{|l|l|l|l|l|}
\hline & Frequency & Percent & Valid Percent & Cumulative Percent \\
\hline $18-21$ & 162 & 54.0 & 54.0 & 54.0 \\
\hline $22-25$ & 94 & 31.3 & 31.3 & 85.3 \\
\hline $26-29$ & 3 & 1.0 & 1.0 & 86.3 \\
\hline $30+$ & 41 & 13.7 & 13.7 & 100.0 \\
\hline Total & 300 & 100.0 & 100.0 & \\
\hline
\end{tabular}

In terms of education, 202 individuals $(67.3 \%)$ were undergraduates, who were in per suit of their graduation. 54 people (18.0\%) had completed their graduation and 44 people (14.7\%) had completed their masters.

Table 3: Frequency distribution of educational status

\begin{tabular}{|l|c|c|c|c|}
\hline Education Level & Frequency & Percent & Valid percent & Cumulative percent \\
\hline Undergraduate & 202 & 67.3 & 67.3 & 67.3 \\
\hline Graduate & 54 & 18.0 & 18.0 & 85.3 \\
\hline Masters & 44 & 14.7 & 14.7 & 100.0 \\
\hline Total & 300 & 100 & 100 & \\
\hline
\end{tabular}

Table 4: Occupation

\begin{tabular}{|c|l|l|l|l|l|}
\hline \multicolumn{2}{|c|}{} & Frequency & Percent & Valid Percent & Cumulative Percent \\
\hline \multirow{4}{*}{ Valid } & None & 246 & 82.0 & 82.0 & 82.0 \\
\cline { 2 - 6 } & Part Time & 37 & 12.3 & 12.3 & 94.3 \\
\cline { 2 - 6 } & Full Time & 17 & 5.7 & 5.7 & 100.0 \\
\cline { 2 - 6 } & Total & 300 & 100.0 & 100.0 & \\
\hline
\end{tabular}

Table 5: Reliability Analysis

\begin{tabular}{|l|l|l|}
\hline Name of Variables & Cronbach's Alpha & N of Items \\
\hline Customer Centric & .866 & 7 \\
\hline Green Environment & .776 & 5 \\
\hline Philanthropism & .901 & 6 \\
\hline Public Awareness & .811 & 5 \\
\hline Customer Shared Value & .917 & 5 \\
\hline Purchase Intention & .835 & 5 \\
\hline
\end{tabular}

The Reliability statistics table provides the Cronbach's Alpha value as (.933) which is a positive sign for this research. The result of this research are adequate in light of the fact that it is more than (.70) which is considered to be the benchmark reliability index. Accordingly 
researcher can state that internal consistency reliability of the things gives great help to investigate writing.

\section{B. Normality Analysis}

Next, researcher analyzed the data to see if the data is normal or not. On the basis of normality, researcher will decide whether researcher will apply parametric or non-parametric tests as the data analysis goes on. The hypothesis of this study is that the data is normal. If the p-value (Sig.) of Shapiro-Wilk is greater than the value of alpha (0.05), then researcher will accept the hypothesis. In the above table, the p-values of Customer Centric, Green Environment, Philanthropy and Public Awareness are all less than 0.05. Only the value of Creating Shared Value exceeds 0.05. Because most of researcher's dimensions have values less than 0.05 , researcher will accept the hypothesis. In short, the data is not normal and hence, researcher will apply non-parametric tests.

\section{Correlation}

Now the researcher applies the correlation test to see which variables associated with the dependent variable of this study. For that, researcher needs to develop hypothesis. The hypothesis of this study is that there exists a relationship between the dependent and the independent variable.

Customer Centric and Green environment have a statistically significant correlated at $(\mathrm{p}<.05)$. The direction of the relationship between these variables is positive (i.e., Customer Centric and Green Environment are positively correlated), meaning that these variables tend to increase together. Philanthropism and Customer centric are significantly correlated with each other at $(\mathrm{p}<.01)$. Philanthropism and Green environment are also significantly correlated at $(\mathrm{p}$ $<.05)$. Public Awareness and Customer centric attitude is also significantly correlated at ( $\mathrm{p}$ .01 ). The relationship between Public awareness and green environment is significant at ( $\mathrm{p}<$ .01). Creating Social Value is significantly correlated with customer centric and green environment at $(\mathrm{p}<.01)$. Purchase intention is dependent variable. The relationship of Purchase intention with Customer centric is significantly correlated at $(\mathrm{p}<.05)$. Purchase intention and Green Environment are significantly correlated at $(\mathrm{p}<.05)$. The relationship of Purchase intention with Philanthropism is significantly correlated at $(\mathrm{p}<.05)$. Purchase intention and Public Awareness are significantly correlated at $(\mathrm{p}<.05)$. The relationship of Purchase intention with creating social value is significantly correlated at $(\mathrm{p}<.05)$. 
Table 6

\begin{tabular}{|c|c|c|c|c|c|c|}
\hline & $\begin{array}{l}\text { Customer } \\
\text { Centric }\end{array}$ & $\begin{array}{l}\text { Green } \\
\text { Environment }\end{array}$ & Philanthropism & $\begin{array}{l}\text { Public } \\
\text { Awareness }\end{array}$ & $\begin{array}{l}\text { Creating } \\
\text { social } \\
\text { Value }\end{array}$ & $\begin{array}{l}\text { Purchase } \\
\text { Intention }\end{array}$ \\
\hline $\begin{array}{l}\text { Customer } \\
\text { Centric }\end{array}$ & 1 & & & & & \\
\hline $\begin{array}{l}\text { Green } \\
\text { Environment }\end{array}$ & $.45^{*}$ & 1 & & & & \\
\hline Philanthropism & $.366^{*}$ & $.428 *$ & 1 & & & \\
\hline $\begin{array}{l}\text { Public } \\
\text { Awareness }\end{array}$ & $.566^{* *}$ & $.60 * *$ & $.52 * *$ & 1 & & \\
\hline $\begin{array}{l}\text { Creating social } \\
\text { Value }\end{array}$ & $.46^{*}$ & $.54 * *$ & $.57^{* *}$ & $.455^{*}$ & 1 & \\
\hline $\begin{array}{l}\text { Purchase } \\
\text { Intention }\end{array}$ & $.58 * *$ & $.70 * *$ & $.59^{* *}$ & $.533 * *$ & $.499 *$ & 1 \\
\hline
\end{tabular}

\section{Regression}

Now the researcher applies the regression test to see which variables affect dependent variable. If the p-value (Sig.) of Purchase Intention, with respect to other variables is greater than the value of alpha (0.05), then researcher will accept hypothesis or vice versa consider the alternative hypothesis, which is that there exists a positive impact of independent variables on dependent variables.

In the above table, the p-values of Customer Centric and Green Environment are greater than 0.05 . Hence, researcher will accept the hypothesis that there is no relation between purchase intention and these two factors. However, the p-value of Philanthropy, Public Awareness and Creating Shared Value is less than 0.05, hence researcher will accept the hypothesis, which states that there does exist a relationship between purchase intention and these three factors. In short, Customer Centric and Green Environment have no link with the Purchase Intention of the customers, whereas Philanthropy, Public Awareness and Creating Shared Value do have an impact on the purchase intention of the consumers.

Table 7

\begin{tabular}{|c|c|c|c|c|c|}
\hline Hypothesis & Variables & $\begin{array}{l}\text { Beta } \\
\text { Values }\end{array}$ & $\begin{array}{l}\text { t- } \\
\text { statistics }\end{array}$ & $\begin{array}{l}\text { p- } \\
\text { statistics }\end{array}$ & $\mathbf{R}^{2}$ \\
\hline H1 & Customer Centric $\longrightarrow$ & 0.136 & 2.207 & 0.02 & \multirow[t]{5}{*}{.35} \\
\hline H2 & Green Environment $\longrightarrow$ Purchase Intention & 0.142 & 2.271 & 0.03 & \\
\hline H3 & Purchase Intention & 0.153 & 1.988 & 0.04 & \\
\hline H4 & 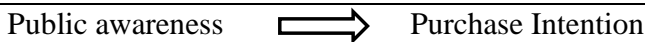 & 0.167 & 2.752 & 0.02 & \\
\hline H5 & Creating Social Value $\longrightarrow$ Purchase Intention & 0.180 & 2.143 & 0.03 & \\
\hline
\end{tabular}

Table: 4.0 


\section{Discussion \& Conclusion}

The limited number of past studies in the area of CSR motives shows that CSR motives have significant impacts on the attitude toward the firm, which in turn, has a significant impact on the purchase intention. This study extends the knowledge in this area of study. The results demonstrate the process by which CSR motives affect the purchase intention of consumers. This study has discover that corporate social responsibility effects purchase intentions of consumers. This study will add value in the knowledge of mangers and other researchers. It will help in understanding purchaser purchasing designs, and their inclinations. This examination will similarly assist managers with lessening the indisputable and intangible cost related with the investigation done to perceive buyer obtaining behavior, tendencies and so on. It will empower advertiser and expert to better grasp buyers and at most fundamental and primal level. The results show that a brand being in conformation with customer centric impacts the purchase intention of customers. It influences the purchaser attitudes. Likewise a brand being in conformation with green environment impacts the purchase intention of customers. People now days are more concerned about the environment. They are adopting green practices to conserve the environment. Same is the case with Philanthropism. The discoveries of this examination exhibit a convincing and extensive clarification of the connection amongst philanthropism and the buy aim of customer. This study explores meaningful effects of public awareness on purchase intention of customers. A brand being in conformation with creating shared value impacts the purchase intention of customers. With the above results researcher can conclude that customer centric, philanthropism, green environment, public awareness and creating social value all these variables effect purchase intention.

\section{A. Limitations and Future Directions}

This investigation isn't exempted from a couple of restrictions. Initial, couple of parts of purchasers' state of mind is not analyzed. As all parts of customer purchase attitude couldn't be explored, a future research ought to be led to analyze every one of the parts of buyer buying mentality and subjective procedure of purchase intention it is proposed that future research should consider a more extensive view. As a result of lacking capital and confinement of time, the examination was done on a restricted casing of shoppers. Many more factors are there that influence purchase intention. So there is a chance to think about different factors too. Keeping in view the span of the populace the sample size can be an inquiry for any investigation. The investigation is led in the center point of educational activities i.e. Lahore which may influence generalizability of results. While other cities especially remote areas are not included in the 
research. Further researches can incorporate the members of a few private and public colleges to achieve more precise discoveries and recommendations. Future analysts with a specific end goal to expand the more summed up results can gather information from more colleges and schools arranged in various urban areas and towns the nation over and contrast the outcomes with get more significant suggestions. The outcomes so accomplished will have more legitimate findings. Another impediment of the exploration is the questionnaire strategy i.e. filling of the survey. This technique here and there unfit to give the genuine reaction the same number of respondents just top off the questionnaire without knowing the significance of the examination and understanding the significance of the inquiry. Subsequently other techniques have ability to take care of this issue if not totally might be to some degree.

\section{B. Implications}

This study has discover that corporate social responsibility effects purchase intentions of consumers. This study will add value in the knowledge of mangers and other researchers. It will help in understanding purchaser purchasing designs, and their inclinations. This examination will similarly assist managers with lessening the indisputable and intangible cost related with the investigation done to perceive buyer obtaining behavior, tendencies and so on. It will empower advertiser and expert to better grasp buyers and at most fundamental and primal level. This examination will likewise cover the pragmatic holes. Investigation will be helpful for administrators and analysts. This examination will contribute through and through in existing writing and will enhance the generalizability of past examinations, coordinated on different settings and setting. 
Pakistan Journal of Humanities and Social Sciences, 6(4), 2018

\section{References}

Ali, I. (2011). Influence of corporate social responsibility on development of corporate reputation and customer purchase intentions.

Ali, I., Alvi, A. K., \& Ali, R. R. (2012). Corporate Reputation, Consumer Satisfaction and Loyalty. Romanian Review of Social Sciences, (3).

Beckmann, S. C. (2007). Consumers and corporate social responsibility: Matching the unmatchable. Australasian Marketing Journal (AMJ), 15(1), 27-36.

Beckmann, S. C. (2007). Consumers and corporate social responsibility: Matching the unmatchable? Australasian Marketing Journal (AMJ), 15(1), 27-36.

Bigné-Alcañiz, E., Currás-Pérez, R., Ruiz-Mafé, C., \& Sanz-Blas, S. (2012). Cause-related marketing influence on consumer responses: The moderating effect of cause-brand fit. Journal of Marketing Communications, 18(4), 265-283.

Bigné-Alcañiz, E., Currás-Pérez, R., Ruiz-Mafé, C., \& Sanz-Blas, S. (2012). Cause-related marketing influence on consumer responses: The moderating effect of cause-brand fit. Journal of Marketing Communications, 18(4), 265-283.

Bray, J. P. (2008). Consumer behavior theory: approaches and models.

Bulan, P. Indonesian Consumer Preferences on Green Products.

Carroll, A. (2008). Corporate social responsibility (CSR) and corporate social performance (CSP). Encyclopedia of business ethics and society. Sage, London.

Carroll, A. B. (1999). Corporate social responsibility: Evolution of a definitional construct. Business \& society, 38(3), 268-295.

Carroll, A. B. (2008). A history of corporate social responsibility: Concepts and practices. The Oxford handbook of corporate social responsibility, 19-46.

Čekanavičius, L., Bazytè, R., \& Dičmonaite, A. (2014). Green business: challenges and practices. Ekonomika, 93.

Creyer, E. H. (1997). The influence of firm behavior on purchase intention: do consumers really care about business ethics? Journal of consumer Marketing, 14(6), 421-432.

Creyer, E. H. (1997). The influence of firm behavior on purchase intention: do consumers really care about business ethics? Journal of consumer Marketing, 14(6), 421-432.

Crowther, D. (2008). Corporate social responsibility. Bookboon.

Crowther, D., \& Capaldi, N. (Eds.). (2008). The Ashgate research companion to corporate social responsibility. Ashgate Publishing, Ltd.

David, P., Kline, S., \& Dai, Y. (2005). Corporate social responsibility practices, corporate identity, and purchase intention: A dual-process model. Journal of Public Relations Research, 17(3), 291-313.

David, P., Kline, S., \& Dai, Y. (2005). Corporate social responsibility practices, corporate identity, and purchase intention: A dual-process model. Journal of Public Relations Research, 17(3), 291-313.

Du, S., Bhattacharya, C. B., \& Sen, S. (2007). Reaping relational rewards from corporate social responsibility: The role of competitive positioning. International journal of research in marketing, 24(3), 224-241.

Du, S., Bhattacharya, C. B., \& Sen, S. (2007). Reaping relational rewards from corporate social responsibility: The role of competitive positioning. International journal of research in marketing, 24(3), 224-241.

Fatma, M., \& Rahman, Z. (2016). The CSR's influence on customer responses in Indian banking sector. Journal of Retailing and Consumer Services, 29, 49-57. 
Klein, J., \& Dawar, N. (2004). Corporate social responsibility and consumers' attributions and brand evaluations in a product-harm crisis. International Journal of research in Marketing, 21(3), 203-217.

Klein, J., \& Dawar, N. (2004). Corporate social responsibility and consumers' attributions and brand evaluations in a product-harm crisis. International Journal of research in Marketing, 21(3), 203-217.

Laroche, M., Kim, C., \& Zhou, L. (1996). Brand familiarity and confidence as determinants of purchase intention: An empirical test in a multiple brand context. Journal of business Research, 37(2), 115-120.

Lee, K. H., \& Shin, D. (2010). Consumers' responses to CSR activities: The linkage between increased awareness and purchase intention. Public Relations Review, 36(2), 193-195.

Lichtenstein, D. R., Drumwright, M. E., \& Braig, B. M. (2004). The effect of corporate social responsibility on customer donations to corporate-supported nonprofits. Journal of marketing, 68(4), 16-32.

Lichtenstein, D. R., Drumwright, M. E., \& Braig, B. M. (2004). The effect of corporate social responsibility on customer donations to corporate-supported nonprofits. Journal of marketing, 68(4), 16-32.

Loudon, D., \& Della-Bitta, A. (1993). Consumer Behavior (4, h Ed.). McGraw-Hil Inc.

Luo, X., \& Bhattacharya, C. B. (2006). Corporate social responsibility, customer satisfaction, and market value. Journal of marketing, 70(4), 1-18.

Moura-Leite, R. C., \& Padgett, R. C. (2011). Historical background of corporate social responsibility. Social Responsibility Journal, 7(4), 528-539.

Moura-Leite, R. C., \& Padgett, R. C. (2011). Historical background of corporate social responsibility. Social Responsibility Journal, 7(4), 528-539.

Parsa, H. G., Lord, K. R., Putrevu, S., \& Kreeger, J. (2015). Corporate social and environmental responsibility in services: Will consumers pay for it? Journal of retailing and consumer services, 22, 250-260.

Pirsch, J., Gupta, S., \& Grau, S. L. (2007). A framework for understanding corporate social responsibility programs as a continuum: An exploratory study. Journal of business ethics, 70(2), 125-140.

Pirsch, J., Gupta, S., \& Grau, S. L. (2007). A framework for understanding corporate social responsibility programs as a continuum: An exploratory study. Journal of business ethics, 70(2), 125-140.

Ramasamy, B., \& Yeung, M. (2009). Chinese consumers' perception of corporate social responsibility (CSR). Journal of Business Ethics, 88(1), 119-132.

Robinson, S. R., Irmak, C., \& Jayachandran, S. (2012). Choice of cause in cause-related marketing. Journal of marketing, 76(4), 126-139.

Robinson, S. R., Irmak, C., \& Jayachandran, S. (2012). Choice of cause in cause-related marketing. Journal of marketing, 76(4), 126-139.

Rodrigues, P., \& Borges, A. P. (2015). Corporate social responsibility and its impact in consumer decision-making. Social Responsibility Journal, 11(4), 690-701.

Rodrigues, P., \& Borges, A. P. (2015). Corporate social responsibility and its impact in consumer decision-making. Social Responsibility Journal, 11(4), 690-701.

Sen, S., Bhattacharya, C. B., \& Korschun, D. (2006). The role of corporate social responsibility in strengthening multiple stakeholder relationships: A field experiment. Journal of the Academy of Marketing science, 34(2), 158-166.

Sen, S., Bhattacharya, C. B., \& Korschun, D. (2006). The role of corporate social responsibility in strengthening multiple stakeholder relationships: A field experiment. Journal of the Academy of Marketing science, 34(2), 158-166. 
Suliman, A. M., Al-Khatib, H. T., \& Thomas, S. E. (2016). Corporate social responsibility. Corporate Social Performance: Reflecting on the Past and Investing in the Future, 15.

Tian, H., \& Yuan, H. (2013). The contingent effect of corporate social responsibility fit on consumer brand attitude: A research on boundary conditions of consumer attribution. Nankai Business Review International, 4(4), 349-364.

Tian, H., \& Yuan, H. (2013). The contingent effect of corporate social responsibility fit on consumer brand attitude: A research on boundary conditions of consumer attribution. Nankai Business Review International, 4(4), 349-364.

Vaaland, T. I., Heide, M., \& Grønhaug, K. (2008). Corporate social responsibility: investigating theory and research in the marketing context. European Journal of Marketing, 42(9/10), 927-953.

Vaculchuk, Y., Borodkina, N., \& Kobzar, S. (2016). CORPORATE SOCIAL RESPONSIBILITY.

Wongpitch, S., Minakan, N., Powpaka, S., \& Laohavichien, T. (2016). Effect of corporate social responsibility motives on purchase intention model: An extension. Kasetsart Journal of Social Sciences, 37(1), 30-37.

Wongpitch, S., Minakan, N., Powpaka, S., \& Laohavichien, T. (2016). Effect of corporate social responsibility motives on purchase intention model: An extension. Kasetsart Journal of Social Sciences, 37(1), 30-37.

Wu, S. I., \& Wang, W. H. (2014). Impact of CSR perception on brand image, brand attitude and buying willingness: a study of a global café. International Journal of Marketing Studies, 6(6), 43. 